\title{
Alternative Remedies in Resolving Disputes in Transitional Countries and Their Impact in Foreign Direct Investment (FDI): Kosovo Case
}

\author{
Neshat Podvorica \\ Faculty of economics, University of Prishtina "Hasan Prishtina, Kosovo \\ neshat_podvorica@hotmail.com
}

Doi:10.5901/ajis.2015.v4n1s2p159

\begin{abstract}
The purpose of this paper is to present the state and performance on development of alternative mechanisms in resolving disputes in transitional countries. Special significance is given to the impact of these mechanisms in creating an appropriate climate for potential investors to the Balkans countries, with special emphasis in Kosovo. Arbitration and intermediation are seen as opportunities for these countries to guarantee legal security, taking into consideration numerous problems in functioning of the judiciary. A part of Balkans' countries managed to consolidate these mechanisms to solve the problems, but they need support to achieve general business awareness concerning the advantage they have. Kosovo is oriented to create favorable conditions for economic development by attracting foreign investment, whose rights are guaranteed also by the Constitution. FDI is seen as the main potential in economic development of Balkans countries, therefore, they should be dedicated in creating more propitious conditions for investment.
\end{abstract}

Keywords: Arbitration, intermediation, FDI, transition, Kosovo

\section{Introduction}

The effects of global economy influenced the increase of contractual relations among businesses, and that influenced the increase of disagreements, which may be resolved through court remedies or through alternative means, such as arbitration and intermediation. Countries in transitional stages face many problems, and among them there is the lack of legal basis, lack of functioning of the judiciary, lack of knowledge about the new system, such problems encounter the state with many challenges. Therefore, it is important to develop alternative mechanisms for resolving these disputes, which, among others, require also specific knowledge about problems of these challenges.

Alternative dispute resolution (ADR) are of special importance in transitional countries, because there are great distinctions in regards to the legislation they have, and they background in previous systems impacts that foreign investment is not seen very friendly.

FDIs are important in economic development of transitional countries, as they are countries of post war or conflict and they lack financial equity as well as knowledge about functioning of democracy. Whereas, apart from political and social stability, the first requirement the investors would ask for is legal security and efficient mechanisms for dispute resolution in case of any disagreement.

FDIs in Kosovo are mainly concentrated from countries having a long tradition in using ADRs, hence it is of special importance for Kosovo to meet the requirements of investors, taking into account its open approach towards attraction of investment.

\section{Development of Mediation and Arbitration}

These mechanisms are considered as co-supplementary rather than separate mechanisms. In case of disagreements, mediation is recognised as the method that precedes arbitration, because prior to going to arbitration or courts, businesses make efforts to reach agreements among the parties. In regards to the scope that is regulated by mediation, it has a larger scope than arbitration, as it also covers also parts of criminal offences, which is a distinction from arbitration that resolves only legal civil and economic disputes. 


\subsection{Historic background development of mediation}

Introduction of mediation occurred quite early in time, it is estimated that the first case was in relation to the King Mari in $1800 \mathrm{BC}$ in resolving disagreements with other Kings (Barret and Barret, 2004). Mediation mainly used to be conducted ad hoc and implying simpler procedure than those of the institutions that were conducted later on (Conrad, 2011).

According to Kosovo Law, mediation was defined as an extra judicial activity carried out by a third person (mediator), for the purpose of resolving by conciliation disagreements between parties subject to law in accordance with the provisions of this law (Law No 03/L-057).

Mediation had a great development in the past years, in particular in the field of commercial disputes (USAID, 2010), wherein in 2002, UNCITRAL presented a model how mediators can resolve various disputes, meanwhile unifying best mediation policies and to make it as alternative for countries which intend to harmonise their legislation to the international rules (UNCITRAL, 2002). Though this model of law was introduced by UNCITRAL, which covers more the field of commercial relations, it may be used also in non-commercial disputes (USAID, 2010). The same practice is observed also by the European Union, which created the foundation of this field through directives (EU, 2008).

\subsection{Historic background of arbitration}

As the oldest arbitration agreement is considered the agreement between Sumerian cities Lagosh and Ume, in the IV Millennium BC, in relation to administration of borders (Thaçi, 2012). In the course of history, arbitration was often in the service of first countries, according to which private persons contracted their commitment for resolving disputes in order to avoid strict procedural (ritual) formalities of the then courts (Thaçi, 2012). It was better organized mainly in the field of sea trading (history of exports), which disputes were resolved based on ad hoc arbitration. The first states that accepted arbitration by law were England in 1689, France in 1806 and the USA in 1925 (Lew et al. 2003). The first rules of arbitration were approved in the centuries XV and XVI, in the USA, while its development empowered at the beginning of XIX century, which adopted laws foreseeing arbitration as alternative for the courts (Musa, 2012). While international arbitration is introduced in an organized way at the end of XIX century and beginning of XX century, following the adoption of two Hague Conventions of 1899 and 1907, establishment of International Arbitration Tribunal by the International Chamber of Commerce in 1923, followed by conventions that supplemented one another starting from those of Geneva, New York, UNCITRAL Rules, etc. (Lew et al. 2003).

Until the mid of XIX century, the institutional arbitration was dominant, whose role was first of all preservation of good relations among people, who, in a way or another, were obliged to live in community, as in it the case with the family of a relative (Krasniqi, 2011).

Historic background of arbitration in Kosovo: In the former Yugoslavia, the right of arbitration was not allowed at all

between local legal entities, it was only possible in relation to foreign trade (Musa, 2012). On 25 December 1946, the Arbitration Regulation for foreign trade was approved before the Trade Chamber of the SFRY (Official Gazette of the SFRY, 1981).

After the war in 1999, following the functioning of KCC, the regulation on permanent arbitration tribunal was established within the Kosovo Chamber of Commerce (KCC, 1999). This regulation was repealed by the entry into force of the Arbitration Law of 2008 (Law No 02/L-75). Following the entry into force of the law, the act on establishment of Arbitration within the Kosovo Chamber of Commerce and arbitration rules within this Chamber entered into force, wherein as model there were taken the UNICITRAL rules, whereas in 2011, the first arbitrators were designated.

\subsection{Definition of Arbitration}

Arbitration is a modern common method for resolution of disagreements that arise in the course of conducting operations in international trading (Krasniqi, 2011). Arbitration for the foreign trade is an authorized international institution for resolution of conflicts from international legal business relations (Smaka and Gojani, 2012). Arbitration is a process for resolution of disputes that distinguishes from court proceedings; nevertheless in this process, one or more neutral persons (arbitrators) issues a judgment based on the merits of the case, after presentation of evidence and arguments by the parties in the dispute (USAID, 2010).

Among main definitions on arbitration and including elements, it may be mentioned the one of Rene David, which describes arbitration stating that it is a device whereby the settlement of a question, which is of interest for two or more persons - the arbitrator or arbitrators - who derive their powers from a private agreement, note for the authorities of a 
State, and who are to proceed and decide the case in the basis of such an agreement (Lew, et al. , 2003).

\section{Alternative Dispute Resolution in Transitional Countries}

ARDs have a greater significance in the transitional countries, due to the lack of functioning and efficiency of judiciary, they fulfil its gaps. These countries, apart from the change of economic system are in the process of many other changes, the so called informal institutions of a state, such as culture, habits, codes, various networks (Fabry and Zeghni, 2010), therefore, the judicial system cannot afford all of them. The arbitration services have some advantages in comparison to the services of the courts, and such services probably are more important in the post-communist countries (Schonfelder, 2007). However, the ADR capacities are limited due to time frames and various legal obstacles, as well as the lack of previous practice, or case laws, make the work of arbitration difficult.

Investors in Balkans' states, almost all of them, insist in resolving disputes through arbitration, and the resolution is conducted in the arbitrations of western countries (Schonfelder, 2007), which means that there is no trust in such mechanisms. A part of these countries commenced with the transitional process many years ago, i. e. Albania, Bosnia and Herzegovina and Rumania, in such countries the rule of law, implementation of contracts, and others got worse (Fabry and Zeghni, 2010), which indicates the necessity of ADRs in protection of foreign investors.

Some Balkans countries have made changes with regard to the law on arbitration and its harmonization with the new rules of the Model Law of UNCITRAL, such as Croatia in 2001, and Serbia and Macedonia in 2006 (GIZ, 2011).

Balkans countries has signed various contracts such as CISG, which entered into force in 1988, but following the disintegration of the former Yugoslavia, its member states became members as independent countries. In Albania, it entered into force at the beginning of 2010 (GIZ, 2011). The trust in ADR, during this period of time, was increased in some states, as it is the case with Croatia, wherein in 2002, the value of resolved disputes in arbitration was over 6 million Euro, whereas the value of disputes resolved by the courts was around 160. 000 Euro (Schonfelder, 2007). Having some distinctions, the general level of development of mechanisms in resolving disputes have an approximate development in the countries of the region (WB, 2010).

\section{The Impact of Arbitration and Mediation in FDls}

Investors prior to going to a country with their investment, apart from checking economic factors (natural resources, manpower, strategic position), political social security, they also look for sustainable, reliable, unbiased and professional mechanisms in resolving disputes (USAID, 2009). Therefore, legal security means only the right for the investors to withdraw the capital whenever they want from the country without any obstacles as foreseen by the Constitution of Kosovo (Article 119. 6), and to have the opportunity to resolve the contractual disputes as soon as possible. Therefore, Kosovo should give priority to increase the capacities of ADRs.

Taking into account that the majority of FDI come from multinational corporations, then various studies show that more than two thirds of them prefer arbitration in resolving disputes to the regular court system (Pouget, 2013). The field of investment was regulated properly by the Washington Convention of 1965, which is now known as: the Convention on Settlement of Investment Disputes between States and Nationals of Other States in the field of investment, which was sponsored by the World Trade Organization (Mëneri, 2012). Afterwards, the Geneva Convention regulates the arbitration forums either of regular arbitration or ad hoc, which does not make any distinction for the parties that can be part of it (Mëneri, 2012).

Investors, prior to using the ADRs, they commence with negotiations that address to a third party, who shall work impartially (Mëneri, 2012), and in case they do not reach an agreement, they proceed with the proceedings before the ADR, Investors are interested in ADRs, because they are more flexible and parties may be able to determine some rules, depending on the specifications of the contract (World Bank, 2010).

FDIs in some countries come from some countries or regions that may have similar specifications, the case of Bosnia and Herzegovina, wherein investments are mainly concentrated from Russia, Serbia, countries that have no tradition in application of arbitration (Gide Loyrette Nouel, 2013). Therefore, the general economic policy has its impact as well.

Attraction of FDIs is difficult, because they are mainly small countries and they have small market for huge investment (Fabry and Zeghni, 2010). Great significance in economic development is paid by small and medium enterprises, however, these enterprises in trade relations to the enterprises of neighbouring countries face different laws and they need to consult legal advisors in drafting contracts (GIZ, 2011), therefore, functioning of the ADRs would 
influence in increasing the knowledge in terms of non-compliance with contracts.

\section{Alternative Mechanisms for Dispute Resolution in Kosovo}

The Republic of Kosovo is open for FDIs and in case of any dispute it accepts the arbitration for resolution of the dispute, therefore, the setting for investors that sign contracts with Kosovo are secure, because they have the possibility to choose also international arbitrations, because such investments are usually huge, such as construction, privatization or concession of national resources.

Efficiency of the arbitration implies more on FDI, which are conducted between foreign investors and investors in Kosovo, in which cases, in order for arbitration to be valid it is required to have the consent of the parties explicitly. It is important to emphasise that there has been a spirit of pro international legislation, which approach is reflected in the Constitution of the Republic of Kosovo, which adopts almost all of the international conventions (Constitution, Article 171), even though in some cases it accepted unilaterally due to the lack of recognition by the international organizations. Moreover, the secondary legislation is in harmony with the European one, especially with the EU Detectives, wherein the central institutions have established instructions on approximation of legislation (Government of Kosovo, 2015). In this light, the legislation on mediation and arbitration was adopted, in Article 18 of the Law on Foreign Investment, it is stated that Kosovo shall accept all of the decisions issued by the arbitrations (Law No. 04/L-220). Therefore, after the issuance of an arbitration decision, the decision is applicable in Kosovo in compliance with the New York Convention (USAID, 2009).

Development of ADRs in Kosovo is important because of the problems in functioning of the courts, which face a judge caseload number, wherein the number amounted 400. 000 cases in 2013 (Kosovo Judicial Council, 2014). Moreover, corruption in the judiciary system and political influence on it (European Commission, 2013), are impacting on the fact that businesses have difficulties in convincing partners for alternative paths.

\section{Structure of the FDls and their Guarantee in Kosovo}

The number of foreign businesses that come to Kosovo are mainly concentrated in the field of trade and partly in services (Ministry of Foreign Affairs, 2015), such fields in which contractual relations are numerous and evolutionary comparing it to other fields. It is important that businesses in contractual relations have into account that in case of any dispute, they may address to efficient mechanisms for resolution of problems. Therefore, investors should be convinced that there is sufficient basis for acceptance of national arbitration as a resolution in case of any dispute. Even though the law on arbitration describes in some case the percentage of tariffs depending on the value of dispute (Law No 02/L-75), on the other hand the administrative expenses are low (Kosovo Chamber of Commerce, 2011), due to the low standard and the cost of life in Kosovo.

Taking into account the structure of FDIs that mainly come from European countries (Central Bank of the Republic of Kosovo, 2014), which have some tradition in application of the ADRs, in that case Kosovo should do more that through their development to provide more appropriate conditions to the investors and to make it as an advantage in relation to the neighbouring countries.

Functioning of ADRs is not only connected to their internal capacity building, but it also depends on the rule of law (World Bank, 2010), therefore, Kosovo should build up independent and efficient judiciary institutions. Moreover, shortening of the execution period of the decision issues by the ADRs should be a priority.

\section{Conclusion}

Economic development of transitional countries is mainly dependant of FDIs, therefore, creation of mechanisms for protection of investors is considered as preconditions for development. At the first stage of transition, FDIs are mainly concentrated on privatization, which investment is generally certain in case of disputes, because the state stands behind the contracts. In order to increase or maintain the trend of FDIS, the countries of the region should create more favourable preconditions so that there is investment also in the private sector.

The efficiency of ADRs in resolving disputes is positively related to the functioning of judiciary, because the countries that have functional judiciary also guarantee fast resolution of disputes, and businesses have the benefit to accelerate the proceedings through mediation or arbitration in order to use the advantages that are offered by these mechanisms. 
The countries of the region have made significant steps forward to functioning of ADRs, however, the lack of trust in the judiciary institutions in general has had an impact on these mechanisms as well.

Kosovo has been committed to create greater opportunities for FDIs, in some case by accepting obligation unilaterally from the international organizations. Kosovo has established a good legal foundation for ADRs, however, it is requited awareness, especially for the businesses in applying provisions that would direct to such mechanisms, and reduction of period for execution of the decisions issued by the ADRs should be a priority.

\section{References}

Barrett, Jerome \& Barrett, Joseph. , (2004). A history of alternative dispute resolution: the story of a political, cultural, and social movement. ISBN 0-7879-6796-3.

Central Bank of the Republic of Kosovo, (2014). Annual Report 2013. Prishtinë.

Daly, C. , (2011). Accredation: Mediation's path to professionalism.

World Bank, (2010). Investin across border 2010. Washington.

European Commission, (2013). Kosovo 2013 progress report. http: //ec. europa. eu/.

European Parliament, (2008). Directive 2008/52/EC of the European Parliament and of the Council. Official Journal of the EU.

Fabry, N. , \&Zeghni, S. , (2010). Invard FDI in seven transitional countries of south eastern Europe: a quest of institution based attractiveness. Eastern journal of European studies, Volume 1.

Gide LoyretteNouel, (2013). South east Europe arbitration. No. 1.

GIZ, (2011). Implementation of the United Nation Convention on the international sale of goods and of the system of International Commercial Arbitration in Southeast Europe. Germany.

Kosovo Chamber of Commerce, (2011). Vendim për shpenzimet e procedurës. Prishtinë.

Kosovo Judicial Council, (2014). Kosovo judicial Council annual report. http: //www. kgjk-ks. org/?cid=2,130.

Krasniqi, A. , (2011). Ligji Model UNICITRAL për arbitrazhin e tregtisë ndërkombëtare. Revistë shkencore shoqërore- ekonomike, Administrim Biznesi Nr. 3. 2011.

Official Gazzete. Constitution of the Republic of Kosovo. https: //gzk. rks-gov. net/default. aspx.

Lew, J. , Mistelis, L. , Kroll, S. , (2003). Comparative International Commercial arbitration. Kluwer Law International

Official Gazzete, Law on arbitration. Nr. 02/L-75. https: //gzk. rks-gov. net/ActDetail. aspx?ActID=2579.

Official Gazzete, Law on meditation. Nr. 03/L-057. http: //gzk. rks-gov. net/ActDetail. aspx?ActID=2592

Official Gazzete. Law on foreign investment. Nr. 04/L-220. https: //gzk. rks-gov. net/ActDetail. aspx?ActID=8982.

Mëneri, S. (2012). E drejta e arbitrazhit dhe e ndërmjetësimit ndërkombëtar tregtar. Tiranë

Ministry of foreign affairs, (2015). http: //www. mfa-ks. net/page=1,119.

Musa, M. , (2012). E drejta e arbitrazhit. Gjilan.

Pouget, S. , (2013). Arbitrating and mediating disputes. Policy research Working paper.

Arbitration Regulation on foreign trade, (Official Gazette of FPRY, No. 28/58), and Arbitration Regulation on foreign trade, Official Gazette of SFRY, 1981.

Regulation on Permanent Arbitration Tribunal of 1999, which entered into force after the approval by the Assembly of the Kosovo Chamber of Commerce in 1999.

Schonfelder, B. , (2007). The puzzling underuse of arbitration in post communist south eastern Europe. Post Communist economies. Vol. 19, No. 1.

Smaka, R. , Gojani, S. , (2012). E drejta Biznesore. Prishtinë.

Thaci, R. , (2012). E drejta e arbitrazhit. Prishtinë.

USAID, (2010). The program Systems for Enforcing Agreements and Decisions (SEAD), report and recommendations for successful and effective development and implementation of the system for dispute resolution alternatives.

USAID, (2009). Foreign Investment. Prishtinë. 
